\title{
Promotion of intragranular co-aggregation with LH by enhancement of secretogranin II storage resulted in increased intracellular granule storage in gonadotrophs of GnRH-deprived male mice
}

\author{
J. L. Crawford*, J. R. McNeilly, L. Nicol and A. S. McNeilly ${ }^{\dagger}$ \\ MRC Human Reproductive Sciences Unit, Centre for Reproductive Biology, \\ The University of Edinburgh Chancellor's Building, 49 Little France Crescent, \\ Old Dalkeith Road, Edinburgh EH16 4SB, UK
}

Intracellular associations indicate that granins may play a role in the regulatory mechanisms involved in differential secretion of gonadotrophins. The effect of GnRH on mRNA expression, storage and secretory patterns of granins and gonadotrophins was investigated in male mice. GnRH antiserum (G/A) was injected into mice in the treatment group $(n=15)$ at $12 \mathrm{~h}$ intervals for 2 days and a subset $(n=9)$ was killed. Buserelin $(G / A+B)$ was administered to the remaining mice $(n=6)$, which were killed 2 h later; control mice $(n=6)$ were killed at the onset of the study. LH $\beta$ mRNA content was lower in G/A and G/A + B mice compared with controls, whereas plasma LH concentrations were higher in $\mathrm{G} / \mathrm{A}+\mathrm{B}$ mice. FSH $\beta$ mRNA content did not change, whereas plasma $\mathrm{FSH}$ concentrations were lower in G/A mice compared with controls, and higher in G/A + B mice compared with both G/A and control mice. Secretogranin II (SgII) and CgA mRNA contents were not different between experimental groups. There were more granules per gonadotroph in G/A mice, and considerably

\section{Introduction}

Granins are acidic glycoproteins that possess aggregative (Gerdes et al., 1989; Gorr et al., 1989) and calcium-binding (Cozzi and Zanini, 1986; Reiffen and Gratzl, 1986) properties, and are closely associated with gonadotrophins at the subcellular level (Watanabe et al., 1991, 1993; Jeziorowski et al., 1997). Hence, granins may be involved in the intracellular regulation of differential secretion of gonadotrophins in the specialized anterior pituitary cell, the gonadotroph. The regulation of pulsatile secretion of $\mathrm{LH}$ and of tonic secretion of $\mathrm{FSH}$ is complex and involves interactions between $\mathrm{GnRH}$, activin, inhibin and ovarian-

*Present address: Reproductive Biology Group, AgResearch, Wallaceville Animal Research Centre, PO Box 40063, Upper Hutt, New Zealand

${ }^{+}$Correspondence

Email: a.mcneilly@hrsu.mrc.ac.uk fewer after Buserelin treatment. Immunogold labelling of gonadotrophs revealed the presence of $\mathrm{LH}^{+\mathrm{ve}} / \mathrm{SgII}+\mathrm{ve}$ and $\mathrm{LH}^{+\mathrm{ve}} / \mathrm{SgII}{ }^{-\mathrm{ve}}$ granules, and negligible numbers of $\mathrm{LH}^{-\mathrm{ve} / S g I+\text { +ve }}$ granules. Both the numbers of $\mathrm{LH}^{+\mathrm{ve} / S g I I^{+v e}}$ granules and overall granule antigenicity for SgIl were higher in G/A mice compared with controls and G/A+B mice. In contrast, there were fewer $\mathrm{LH}^{+\mathrm{ve}} / \mathrm{SgIl}{ }^{-\mathrm{ve}}$ granules per gonadotroph in G/A mice compared with controls. In conclusion, absence of $\mathrm{GnRH}$ input to the pituitary gland resulted in preferential storage of SgII and subsequently increased intragranular co-aggregation with LH. Administration of Buserelin to G/A mice resulted in the apparent release of $\mathrm{LH}^{+\mathrm{ve}} / \mathrm{SgII}{ }^{+\mathrm{ve}}$ granules that was reflected by an increase in plasma LH concentrations, indicating that these granules were in the regulated secretory pathway. In contrast, secretion of $\mathrm{LH}^{+\mathrm{ve}} / \mathrm{SgII}{ }^{-v e}$ granules did not appear to be influenced by the actions of Buserelin and, therefore, may have been destined for constitutive release, possibly to maintain basal plasma LH concentrations. derived steroids (Clarke and Cummins, 1982; Levine et al., 1985; Farnworth et al., 1988; Farnworth, 1995). Specific inhibition of GnRH influence throughout administration of a GnRH agonist for 6 weeks in ewes completely abolished both pulsatile $\mathrm{LH}$ release and responsiveness of $\mathrm{LH}$ and $\mathrm{FSH}$ to $\mathrm{GnRH}$ stimulation, and also reduced both $\mathrm{LH} \beta$ and $\mathrm{FSH} \beta$ mRNA contents (to $5 \%$ and $30 \%$ of luteal control values, respectively), and pituitary content of $\mathrm{LH}$ and $\mathrm{FSH}$ (to $3 \%$ and $30 \%$ of control values, respectively). The significant reduction in $\beta$-subunit gene expression of both gonadotrophins to basal values was associated with only a $50 \%$ reduction in plasma concentrations of $\mathrm{LH}$ and $\mathrm{FSH}$ (McNeilly et al., 1991), demonstrating that LH and FSH are secreted constitutively, as well as via the regulated secretory pathway. It is likely that both constitutively and regulatory released granules are contained within the same gonadotroph. In sheep, Crawford et al. (2000) showed that $24 \mathrm{~h}$ after an exogenously induced preovulatory LH surge, $100 \%$ of gonadotrophs observed were devoid of properly formed 
granules, which was consistent with an absence in pulsatile LH secretion, indicating that all gonadotrophs contained some stored LH that was released only on extracellular stimulation. However, basal $\mathrm{LH}$ concentrations in these animals remained unaltered, confirming that at least a small proportion of LH was being released constitutively from some or all gonadotrophs (Crawford et al., 2000). In addition, three types of granule were identified in gonadotrophs of the rat, and granule populations shifted in males after stimulation by either castration or $\mathrm{GnRH}$ treatment in males (Watanabe et al., 1993, 1998a), as well as in females during the oestrous cycle (Watanabe et al., 1998b). Small $\mathrm{LH}$ - and Sgll-positive granules, and large $\mathrm{FSH}$ - and $\mathrm{CgA}-$ positive granules, were located in gonadotrophs of male and female rats. After stimulation in male rats and at impending ovulation in female rats, a third type of intermediate-sized granule appeared, which contained an electron-dense LH- and Sgll-positive core, and an electronlucent CgA-positive outer region.

The mechanism through which granins may act as regulatory agents in differential gonadotrophin sorting, packaging and trafficking is unknown, although the potential role of a highly conserved $\mathrm{N}$-terminal disulphidebonded loop positioned on chromogranin $\mathrm{A}(\mathrm{CgA})$ and particularly chromogranin $\mathrm{B}(\mathrm{CgB})$ in the sorting of regulated proteins has received attention. Prevention of disulphide bond formation of $\mathrm{CgB}$ in a rat neuroendocrine cell line PC12 resulted in mis-sorting of $\mathrm{CgB}$ to the constitutive pathway (Chanat et al., 1993, 1994; Krömer et al., 1998). Alternatively, the addition of the disulphidebonded loop region of $\mathrm{CgB}$ on to a constitutively secreted protein was sufficient to redirect the fusion protein into a regulated pathway (Glombik et al., 1999), apparently mediated through binding to a sorting receptor within the trans-Golgi network, such as the membrane-associated carboxypeptidase E (Cool et al., 1997). This theory was later contested by several findings including a recently discovered alternative role of the disulphide loop in homodimerization in CgA (Thiele and Huttner, 1998), the absence of the first cysteine residue at the $\mathrm{N}$-terminal region failing to prevent anchorage to vesicle membrane-coupled columns (Yoo and Kang, 1997), and a lack of correlation between redox state of the loop in situ and entry of $\mathrm{CgB}$ into the regulated secretory pathway (Arvan and Castle, 1998). Moreover, it has recently been shown that $\mathrm{CgA}$ contains a binding site for inositol $(1,4,5)$-triphosphate $\left(\mathrm{IP}_{3}\right)$ receptor $(\mathrm{Yoo}, 2000)$, a receptor that also functions as a $\mathrm{Ca}^{2+}$-channel within secretory granule membranes (Yoo, 1994; Yoo et al., 2000).

Despite a very small number of studies on the intracellular associations between granins and gonadotrophins in the rat (Watanabe et al., 1991, 1993, 1998a,b), the benefits of studying the relationship between granins and gonadotrophins in mice are considerable in view of the wide range of transgenic mice models available. Therefore, the aim of the present study was to define the mechanisms through which granins may facilitate synthesis, and storage or secretion of gonadotrophins from gonadotroph cells in male mice. Transcriptional, storage and secretory relationships between granins and gonadotrophins in male mice deprived of $\mathrm{GnRH}$ input through administration of $\mathrm{GnRH}$ antibody and then subsequently stimulated with $\mathrm{GnRH}$ agonist were investigated. Shifts in granule populations in relation to morphology and antigenicity for gonadotrophins and granins were investigated and correlated with alterations in their transcription and secretion to determine the intracellular processing mechanisms.

\section{Materials and Methods}

\section{Animals and experimental design}

Wild-type (WT; $n=21)$ male mice were used in this experiment. Six mice were killed at the onset of the study to act as controls. Four injections (i.p.) of $\mathrm{GnRH}$ antiserum (0.1 ml G/A; Clarke et al., 1978; Fraser et al., 1981; McNeilly et al., 1984) were administered at $12 \mathrm{~h}$ intervals to 15 mice; nine of these G/A-treated mice were killed after the final injection. Synthetic GnRH was administered by i.p. injection (50 ng Buserelin; Sigma Chemical Co., St Louis, $\mathrm{MO} ; \mathrm{G} / \mathrm{A}+\mathrm{B}$ group) to the other six G/A-treated mice, which were killed $2 \mathrm{~h}$ later. A blood sample was collected immediately before death from all animals and the pituitary glands were extracted immediately after death.

Each pituitary gland was weighed and divided transversely into two evenly sized pieces, each containing a similar area of anterior pituitary. One half of the pituitary gland from each animal was randomly allocated for storage in liquid nitrogen for molecular biological analysis. The other half was further divided evenly in an anteroposterior direction and randomly allocated for either processing for confocal microscopy or transmission electron microscopy (TEM).

\section{RNA extraction and real-time PCR}

$\mathrm{LH} \beta, \mathrm{FSH} \beta$, Sgll and CgA mRNA contents were determined using a quantitative real-time PCR method. Frozen pituitaries were transferred directly to RNAzol B (AMS Biotechnology, Witney) and total RNA was extracted using the method recommended by the manufacturer. An aliquot of $800 \mathrm{ng}$ in $8 \mu \mathrm{l}$ from each total RNA sample was treated with DNase I from DNA-free ${ }^{\circledR}$ kit (Ambion, Inc., Austin, TX) following the manufacturer's instructions to remove any residual DNA. A portion (300 ng; $40 \mathrm{ng} \mu \mathrm{l}^{-1}$ ) of DNasetreated total RNA from each sample was reverse-transcribed using reagents including oligo $d(T)^{16}$ provided with Taqman reverse transcription reagents kit (PE Biosystems, Warrington) in accordance with the manufacturer's instructions. A programme of $10 \mathrm{~min}$ at $25^{\circ} \mathrm{C}, 30 \mathrm{~min}$ at $48^{\circ} \mathrm{C}$ and $5 \mathrm{~min}$ at $95^{\circ} \mathrm{C}$ was performed on a PTC-100 programmable thermal controller (GRI; Felsted, Dunmow).

Primers and probes were designed using the computer package 'Primer Express' (PE Biosystems). Primers and FAM-labelled probes for $\mathrm{mLH} \beta$ (forward primer: TGTCCTAGCATGGTCCGAGTACT; reverse primer: AGGGCTACAG- 
GAAAGGAGACTATG; probe: CGGCTGCTTTGCTCCTGTGC), $m F S H \beta$ (forward primer: GGAGAGCAATCTGCTGCCATA; reverse primer: GCAGAAACGGCACTCTTCCT; probe: CTGTGAATTGACCAACATCACCATCTCAGTAGA), mSgll (forward primer: CAAACAGACAGTACCTGGA; reverse primer: AGGGAAATTGGGCATTAAAGC; probe: TCCTGAAAGTGCTGGAGTACCTCAACCA) and mCgA (forward primer: CCCACTGCAGCATCCAGTT; reverse primer: CCGACTGACCATCATCTTTCTG; probe: CCACTTCCATGCAGGCTACAAAGCGA) were also developed by PE Biosystems. Ribosomal 18S primers and the VIC-labelled probe were supplied in a Taqman ribosomal RNA control reagents kit (PE Biosystems).

A reaction mix for real-time PCR was prepared by combining $1 \times$ Taqman universal PCR master mix, specific forward $\left(300 \mathrm{nmol} \mathrm{I}^{-1}\right)$ and reverse $\left(300 \mathrm{nmol} \mathrm{I}^{-1}\right)$ primers, and specific Taqman probe $\left(200 \mathrm{nmol} \mathrm{I}^{-1}\right)$ for the mRNA of interest, ribosomal $18 \mathrm{~S}$ forward $\left(50 \mathrm{nmol} \mathrm{I^{-1 } )}\right.$ and reverse $\left(50 \mathrm{nmol} \mathrm{I}^{-1}\right)$ primers and ribosomal $18 \mathrm{~S}$ probe $\left(200 \mathrm{nmol}^{-1}\right)$. Samples were prepared in duplicate by placing aliquots of $48.88 \mu \mathrm{l}$ reaction mix and $3.12 \mu \mathrm{l}$ cDNA sample into autoclaved RNase-free $0.25 \mathrm{ml}$ Eppendorf tubes and mixing well. Two $25 \mu \mathrm{l}$ aliquots from each tube were transferred to adjacent wells in a 96-well real-time PCR plate. Optical caps were fixed on to the plates and the reaction was run on ABI Prism 7700 (PE Biosystems) using standard conditions. Controls included samples that underwent reverse transcription PCR with the exclusion of Multiscribe reverse transcriptase to check the effectiveness of DNase treatment, and reactions that omitted addition of template. Before analysis, serial dilutions of a sample (1:1 to $1: 64)$ to ensure normalization of the amount of RNA used were made, and the line of best fit was \pm 0.1 when $\Delta \Delta C T$ was plotted against log (input RNA). Quantification of samples was performed by $\Delta \Delta C T$ method (Bulletin No. 5; PE Biosystems).

\section{Gonadotrophin radioimmunoassays}

Reagents were supplied by the NIADDK and concentrations of plasma $\mathrm{LH}$ and $\mathrm{FSH}$ were measured by radioimmunoassay; all samples were included in duplicate in the same assay. The reference preparation used was rat LH-RP- 1 and rat FSH-RP-3, and the sensitivity of the assays was 0.2 and $1.2 \mathrm{ng} \mathrm{ml}^{-1}$ for $\mathrm{LH}$ and $\mathrm{FSH}$, respectively. The intra-assay coefficients of variation were $<10 \%$ (McNeilly et al., 1996, 2000).

\section{Confocal microscopy}

The antisera used included a monoclonal antiserum against bLH $\beta$ (518B7; J. F. Roser, Department of Animal Science, University of California, CA; Matteri et al., 1987) and rabbit-raised antisera against hFSH $\beta$ (M91; S. Lynch, Birmingham), bSgll (Pel-Freez Biologicals, Rogers, AR) and bCgA (INCSTAR Corporation, Stillwater, MN).

Pituitary pieces were fixed in Bouin's fixative for $6-8 \mathrm{~h}$ before transfer to $70 \%(\mathrm{v} / \mathrm{v})$ ethanol for storage until processing. Tissue was rehydrated with $50 \%(\mathrm{v} / \mathrm{v})$ ethanol, $25 \%(\mathrm{v} / \mathrm{v})$ ethanol and $0.01 \mathrm{~mol}^{\mathrm{PBS}} \mathrm{I}^{-1}$ (PBS tablets; Sigma Chemical Co.) for $1 \mathrm{~h}$ each at room temperature, and then incubated overnight in permeabilization/blocking buffer (P/B buffer; $1 \%(\mathrm{w} / \mathrm{v}) \mathrm{BSA}, 10 \%$ normal goat serum (NGS) and $0.003 \%(\mathrm{v} / \mathrm{v})$ Triton-X100) at $4^{\circ} \mathrm{C}$. Mixes of $5 \mu \mathrm{g} \mathrm{ml}{ }^{-1} \mathrm{LH}$ antibody, with either 1:200 FSH, 1:500 Sgll or 1:1000 CgA antibodies, were made up in P/B buffer. Each piece of tissue was divided into three and a different antibody mix was added to each triplicate sample and incubated at $4^{\circ} \mathrm{C}$ for $72 \mathrm{~h}$. The tissue pieces were washed twice for $1 \mathrm{~h}$ and then once for $2 \mathrm{~h}$ in $0.01 \mathrm{~mol} \mathrm{PBS} \mathrm{I}^{-1}$ at $4^{\circ} \mathrm{C}$. A mix of secondary antibodies raised in rabbit $(1: 20$ anti-mouse whole molecule IgG TRITC and 1:20 anti-rabbit whole molecule IgG FITC; Sigma Chemical Co.) were diluted in P/B buffer and added to each sample, and then incubated overnight at $4^{\circ} \mathrm{C}$. The tissue was finally washed three times for $1 \mathrm{~h}$ and left overnight in 0.01 mol PBS $\mathrm{I}^{-1}$ at $4^{\circ} \mathrm{C}$. Pituitary pieces were placed on washed glass slides (Chance Propper Ltd, Agar Scientific Ltd, Stanstead) inside adhesive Easi-Seal squares (Hybaid Ltd, Ashford) and mounted in Citifluor AF1 (Glycerol/PBS solution; Citifluor Ltd, London) before being encased with coverslips (Chance Propper Ltd) and sealed with nail polish.

\section{Transmission electron microscopy}

Pituitary tissue pieces were fixed and processed using a modification of a method described in Berryman and Rodewald (1990) that reports high specific staining in pancreatic and jejunum tissue in the rat without sacrificing cell ultrastructure. Modifications included the fixative $(2 \%$ $(\mathrm{w} / \mathrm{v})$ paraformaldehyde, $0.1 \%(\mathrm{v} / \mathrm{v})$ glutaraldehyde $(25 \%$ EM grade; Agar Scientific Ltd), $0.2 \%(\mathrm{w} / \mathrm{v})$ picric acid and

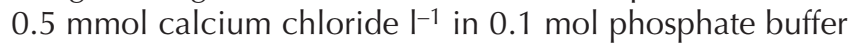
$\mathrm{I}^{-1}, \mathrm{pH} 7.4$ ), embedding resin (Unicryl resin) and embedding capsules (gelatin capsules, size 00; Agar Scientific Ltd).

Ultrathin sections $(80 \mathrm{~nm})$ were cut with a $4 \mathrm{~mm}$ ultradiamond Diatome knife $\left(45^{\circ}\right.$; Leica UK Ltd, Milton Keynes) using a Reichert Jung Ultracut ultramicrotome (Wild Leitz Ltd, Milton Keynes) and mounted on hexagonal 200 mesh gold grids (Agar Scientific Ltd). Gonadotrophs were identified by an immunogold labelling method, using antisera described in the confocal microscopy methods section (dilutions were $5 \mu \mathrm{g} \mathrm{ml}^{-1}$ for $\mathrm{LH}, 1: 200$ for $\mathrm{FSH}, 1: 1000$ for Sgll and 1: 500 for $\mathrm{CgA})$. Grids were blocked with $5 \%(\mathrm{v} / \mathrm{v})$ NGS in Tris histochemical buffer (THB, pH 8.2; BDH Laboratory Supplies) and were then washed in THB. After $2 \mathrm{~h}$ incubation in $\mathrm{LH}$ antiserum, the sections were washed in THB and incubated for a further $2 \mathrm{~h}$ in goat anti-mouse (1:50, $5 \mathrm{~nm}$ diameter gold particles for monoclonal antisera; British Biocell International Ltd) IgG-gold particle conjugates. Sections were washed in THB and then in $d_{d} \mathrm{H}_{2} \mathrm{O}$. This process was repeated for double immunogold labelling using FSH, Sgll or CgA primary antibody, and then goat anti-rabbit (1:50, 10 or $15 \mathrm{~nm}$ diameter gold particles for polyclonal antisera; British Biocell International Ltd) 
IgG-gold particle conjugates secondary antibody. After the final wash step, sections were fixed in $4 \%(\mathrm{v} / \mathrm{v})$ glutaraldehyde. Sections were first stained in $2 \%(\mathrm{w} / \mathrm{v})$ osmium tetroxide (Agar Scientific Ltd) for $1 \mathrm{~h}$ and then triple stained

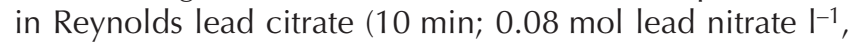
$0.12 \mathrm{~mol}$ trisodium citrate $\mathrm{I}^{-1}$ and $0.16 \mathrm{~mol}$ sodium hydroxide $\left.\mathrm{I}^{-1}\right), 2 \%(\mathrm{w} / \mathrm{v})$ uranyl acetate $(1 \mathrm{~h})$ and again in Reynolds lead citrate $(10 \mathrm{~min})$, washing thoroughly in $\mathrm{dd}_{2} \mathrm{O}$ between incubations. Sections were viewed under a Philips CM 120 Biotwin TEM.

Every second gonadotroph cell in every second hexagonal grid slot was selected until ten immunogoldlabelled gonadotroph cells were identified from $80 \mathrm{~nm}$ thick sections of pituitary tissue from five animals in each group. Within each gonadotroph, two areas of cytoplasm (containing ten granules each) on opposite sides of the nucleus were randomly selected and numbers of $\mathrm{LH}^{+\mathrm{ve}} / \mathrm{SgII}{ }^{+\mathrm{ve}}, \mathrm{LH}^{+\mathrm{ve}} /\left.\mathrm{SgII}\right|^{-\mathrm{ve}}$ and $\mathrm{LH}^{-\mathrm{ve}} / \mathrm{Sgll}{ }^{-\mathrm{ve}}$ granules, as well as number of gold particles per granule, were counted while being viewed on the TEM. The total number of granules per gonadotroph was calculated by counting all granules within these selected cells.

\section{Statistical analysis}

All mass plasma and mRNA values, as well as gold particle and granule counts, are reported as mean \pm SEM. Data were analysed using one-way ANOVA and where a significant $(P<0.05)$ interaction was calculated, a post-hoc Fisher's protected least significant difference test was performed, using Statview statistical computer package (version 4.02; SAS Institute Inc., San Francisco, CA).

\section{Results}

\section{Pituitary masses, plasma LH and FSH concentrations, and granin and gonadotrophin $m R N A$ contents}

There were no significant differences in mean pituitary gland wet mass between experimental groups (data not shown). Mean plasma LH concentrations were significantly higher $(P<0.0001)$ in $\mathrm{G} / \mathrm{A}+\mathrm{B}$ mice compared with controls and $\mathrm{G} / \mathrm{A}$ mice (Fig. 1a). Mean concentrations of plasma FSH were lower $(P<0.001$ and $P<0.0001$, respectively) in $\mathrm{G} / \mathrm{A}$ mice compared with both control and $\mathrm{G} / \mathrm{A}+\mathrm{B}$ mice, but were higher $(P<0.05$ and $P<0.0001)$ after Buserelin treatment compared with both controls and G/A mice (Fig. 1b). Mean LH $\beta$ mRNA contents were lower $(P<0.05)$ in both treatment groups compared with control animals (Fig. 1c). There were no significant differences in mRNA expression for $F S H \beta$ (Fig. 1d), Sgll (Fig. 1e) or CgA (Fig. 1f).

\section{Ultrastructural observations}

Gonadotrophs had a lighter appearance than other types of pituitary cell after an osmium tetroxide and triple staining protocol (Fig. 2a). A dichotomy of granular staining was observed within gonadotrophs of control mice: granules
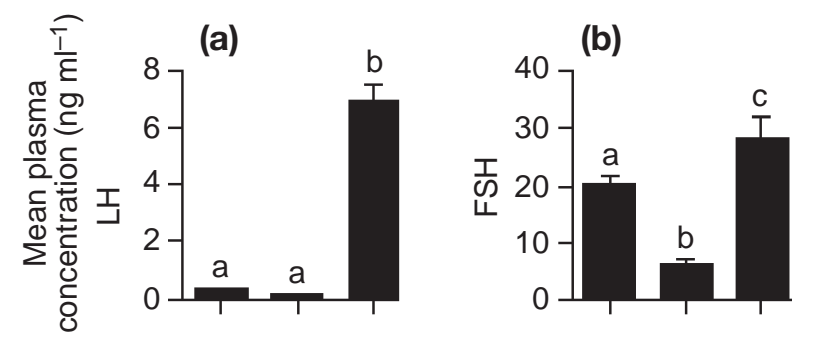

(c)
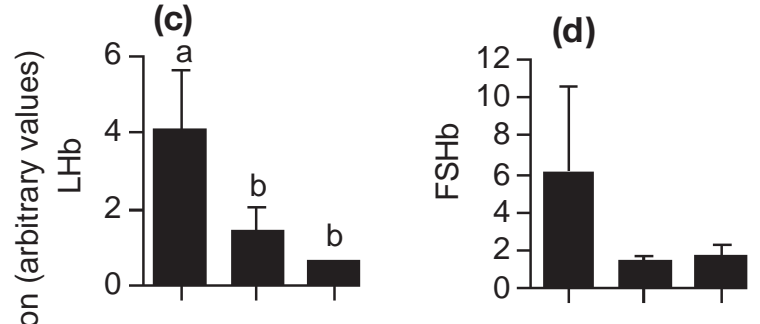

(e)

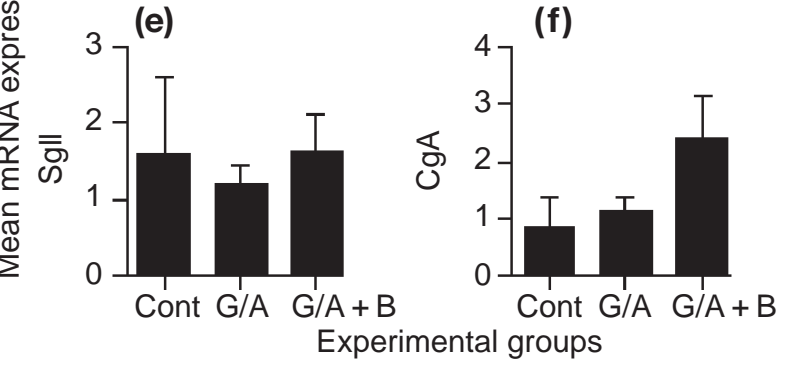

Fig. 1. Mean plasma concentrations of (a) $\mathrm{LH}$ and (b) $\mathrm{FSH}$, and mean mRNA expression of (c) LH $\beta$, (d) FSH $\beta$, (e) Sgll and (f) CgA in control male mice (cont; $n=6$ ), or in male mice treated for 2 days with either $\mathrm{GnRH}$ antiserum (G/A; $n=9)$ or $\mathrm{G} / \mathrm{A}$ followed by a bolus of Buserelin (G/A $+B ; n=6)$. Values are mean \pm SEM. Data were analysed by one-way ANOVA and when a significant interaction was calculated, a post-hoc Fisher's protected least significant difference test was performed. ${ }^{a-c}$ Different letters indicate significant differences between values $(P<0.05)$.

were either completely electron-lucent or contained an electron-dense core surrounded by an electron-lucent outer region ('halo of space'; Fig. 2b). Most granules observed in gonadotrophs from $\mathrm{G} / \mathrm{A}$ mice were of the latter type (Fig. 2C), whereas entirely electron-lucent granules were prevalent in $\mathrm{G} / \mathrm{A}+\mathrm{B}$ mice (Fig. 2d).

\section{Total numbers and antigenicity of granules}

There were more $(P<0.01)$ granules per gonadotroph (80 nm thick section) in G/A mice compared with controls, but after Buserelin treatment fewer granules were observed compared with both G/A $(P<0.0005)$ and control $(P<0.05)$ mice (Fig. 3a).

There were fewer $(P \leqslant 0.005) \mathrm{LH}^{+\mathrm{ve} / S g l l}$-ve and more $(P<0.0005) \mathrm{LH}^{+v e} / \mathrm{Sgll}{ }^{+v e}$ granules in $\mathrm{G} / \mathrm{A}$ mice compared with controls (Fig. 3b). After Buserelin treatment, the number of $\mathrm{LH}^{+\mathrm{ve} / S g I I^{+v e}}$ granules was lower $(P<0.0001)$ compared with G/A mice and similar to values of control animals, whereas numbers of $\mathrm{LH}^{+\mathrm{ve} / \mathrm{Sgll}}{ }^{-\mathrm{ve}}$ granules had not 

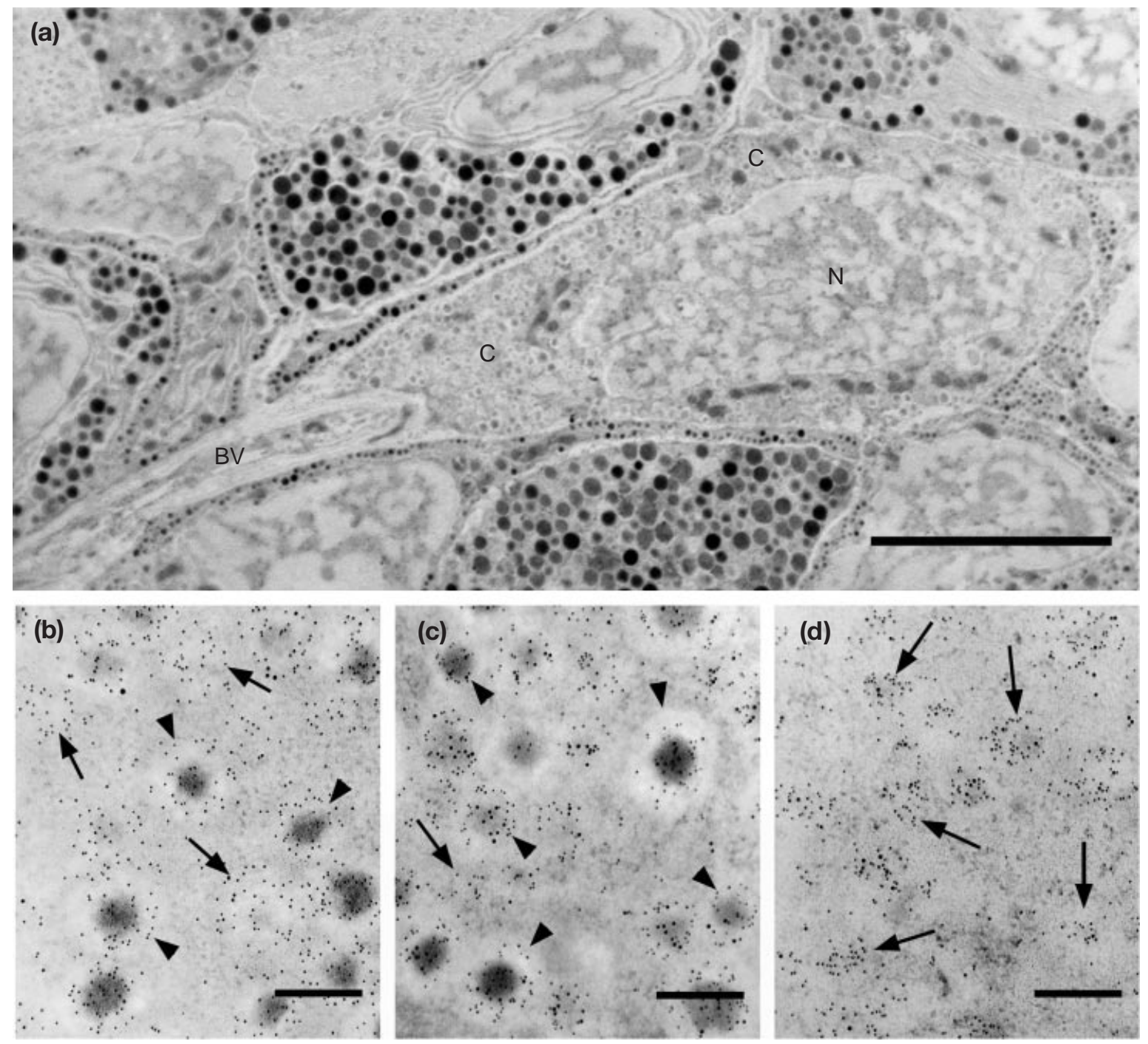

Fig. 2. Transmission electron micrograph of (a) a lightly stained, immunogold-identified (for $\mathrm{LH}$ ) gonadotroph cell from an $80 \mathrm{~nm}$ section of male mouse pituitary gland. An area of cytoplasm shown at higher magnification reveals that the cytoplasm predominantly contained (b) an equal combination of granules that were either entirely electron-lucent (arrows) or contained an electron-dense core surrounded by an electron-lucent outer region (arrowheads) in control mice, (c) granules with an electron-dense core surrounded by an electron-lucent outer region in male mice treated with $\mathrm{GnRH}$ antibody $(\mathrm{G} / \mathrm{A})$, and (d) entirely electron-lucent granules in male mice treated with G/A followed by a bolus of Buserelin $(\mathrm{G} / \mathrm{A}+\mathrm{B}) .5 \mathrm{~nm}$ gold particles depict LH-bound particles $(b-d)$, whereas $15 \mathrm{~nm}$ gold particles depict either $(b, d)$ FSH-bound or (c) Sgll-bound particles. C: cytoplasm; N: nucleus; BV: blood vessel. Scale bars represent (a) $5 \mu \mathrm{m}$ and (b-d) $250 \mathrm{~nm}$.

changed (Fig. 3b). LH-ve/Sgll+ve granules were rarely observed in any gonadotroph. Most $\mathrm{LH}^{+\mathrm{ve} / \mathrm{Sgll}} \mathrm{I}^{+\mathrm{ve}}$ granules appeared to be granules that contained an electron-dense core surrounded by an electron-lucent outer region, whereas most $\mathrm{LH}^{+\mathrm{ve} / \mathrm{Sgll}}{ }^{-\mathrm{ve}}$ granules appeared to be completely electron-lucent in appearance (data not shown).

The amount of $\mathrm{LH}$ in relation to Sgll in individual granules was determined by counting the gold particles bound to these antigens within granules to assess the association between $\mathrm{LH}$ and Sgll during formation of granules and their individual partitioning and storage. This enabled the $\mathrm{LH}^{+\mathrm{ve}} / \mathrm{SgII}{ }^{+\mathrm{ve}}$ granules to be divided into groups dependent on the proportion of LH and Sgll present. The numbers of $\mathrm{LH}^{+\mathrm{ve}} / \mathrm{Sgll}+\mathrm{ve}$ granules in which $\mathrm{LH}$-bound gold particles consisted of $26-50 \%$ and $51-75 \%$ of total gold particles (sum of $\mathrm{LH}$ - and Sgll-bound gold particles) present per granule was higher $(P<0.05$ and $P<0.0005$, respectively) in G/A mice compared with controls (Fig. 3c). After Buserelin administration, the numbers of these granules had decreased $(P<0.05$ and $P<0.0001$, respectively), again to values comparable to those observed in control mice (Fig. 3c). In contrast, the numbers of $\mathrm{LH}^{+\mathrm{ve} / \mathrm{Sgll}}{ }^{+\mathrm{ve}}$ granules 

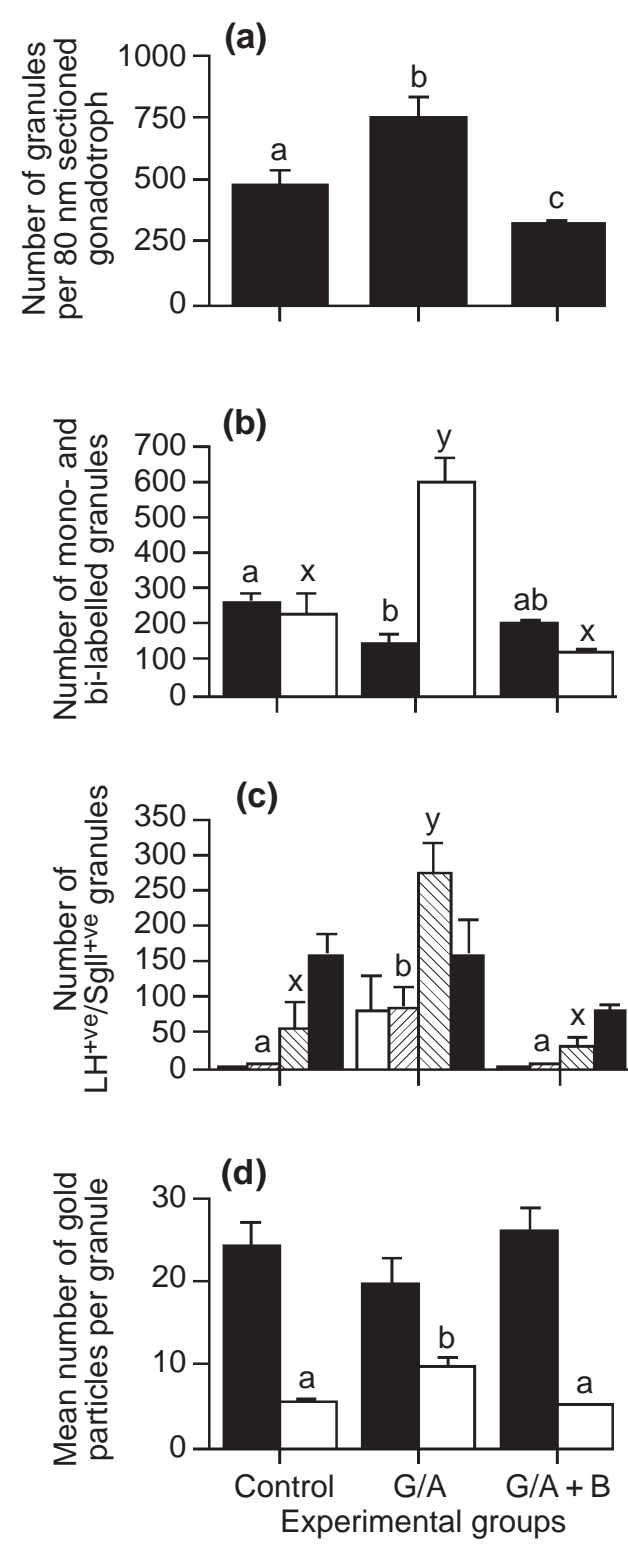

Fig. 3. Changes in mean (a) total number of granules present, (b) number of $\mathrm{LH}^{+\mathrm{ve}} / \mathrm{Sgll} \mathrm{I}^{-\mathrm{ve}}\left(\mathbf{\square}\right.$; secretogranin II) and $\mathrm{LH}^{+\mathrm{ve} / S g I I^{+v e}}(\square)$ granules, and (c) number of $\mathrm{LH}^{+\mathrm{ve}} / \mathrm{SgII} \mathrm{I}^{+\mathrm{ve}}$ granules in which $\mathrm{LH}$ bound gold particles consisted of 1-25 ( $\square$ ), 26-50 ( $\square$ ), 51-75 ( $\square$ ) and $76-99 \%$ ( $)$ of total gold particles (sum of LH- and Sgll-bound gold particles) present per granule. (d) Number of LH-bound ( $\square$ ) and Sgll-bound $(\square)$ gold particles present per granule in $80 \mathrm{~nm}$ thick pituitary sections containing gonadotrophs from control male mice $(n=5)$, or from male mice treated for 2 days with either $\mathrm{GnRH}$ antiserum $(\mathrm{G} / \mathrm{A} ; n=5)$ or $\mathrm{G} / \mathrm{A}$ followed by a bolus of Buserelin $(\mathrm{G} / \mathrm{A}+\mathrm{B} ; n=5)$. Values are mean \pm SEM. Data were analysed by one-way ANOVA and when a significant interaction was calculated, a post-hoc Fisher's protected least significant difference test was performed. ${ }^{a}$ versus ${ }^{b}$ and $x$ versus $y$ indicate significant differences between values $(P<0.05)$.

in which $\mathrm{LH}$-bound gold particles consisted of $0-25 \%$ and $76-99 \%$ of total gold particles present per granule were not different between experimental groups.
Overall granule antigenicity (defined as the total number of gold particles per granule) for Sgll was higher $(P<0.005)$ in $\mathrm{G} / \mathrm{A}$ mice compared with controls, but after Buserelin treatment antigenicity was lower $(P<0.005)$ compared with $\mathrm{G} / \mathrm{A}$ mice and similar to values observed in controls (Fig. 3d). There was no difference in granule antigenicity for LH between experimental groups (Fig. 3d).

In sections immunogold-labelled for $\mathrm{LH}(5 \mathrm{~nm}$ gold particle) and Sgll (15 nm gold particle), the labels for both proteins were located throughout the matrix of the granule (Fig. 4a). On the rare occasion that FSH (15 nm) labelling was observed, the gold particles appeared to be located near the periphery of the granule (Fig. 4b), although labelling for both $\mathrm{FSH}$ and $\mathrm{CgA}$ was sparse, indicating that the TEM processing conditions were too harsh for the preservation of these proteins. Therefore, these results were excluded from the study.

\section{Confocal microscopy observations}

Pituitary sections were immunofluorescently bi-labelled for $\mathrm{LH}$ and $\mathrm{FSH}, \mathrm{LH}$ and $\mathrm{Sgll}$, and $\mathrm{LH}$ and $\mathrm{CgA}$, and were viewed using a confocal microscope. In those sections labelled for LH and FSH, mono-hormonal (for both gonadotrophins) and bi-hormonal gonadotrophs were identified in animals from all groups (Fig. 5a-f). Although the predominant populations were bi-hormonal, there were no differences in the proportions of these populations between groups (data not shown). A similar pattern was observed for sections labelled for $\mathrm{LH}$ and Sgll (Fig. 6a-f); proportions of mono-labelled and bi-labelled cells were not different between experimental groups (data not shown). Sections labelled for $\mathrm{LH}$ and $\mathrm{CgA}$ also contained both mono-labelled (for both antigens) and bi-labelled cells (Fig. 7a-f). Punctate labelling of $\mathrm{CgA}$ was observed in nearly all CgA-positive cells (Fig. 7e,f). Gonadotrophs that were positive for both $\mathrm{LH}$ and $\mathrm{CgA}$ were prevalent in all experimental groups, although the only cell populations that changed were those labelled for $\mathrm{CgA}$ only, with a higher proportion $(P<0.05)$ in $\mathrm{G} / \mathrm{A}+\mathrm{B}$ mice compared with control and G/A mice (data not shown).

\section{Discussion}

This study investigated the relationship between transcription, storage and secretory patterns of granins and gonadotrophins in mice, and has shown for the first time that Sgll does indeed play a role in facilitating storage and secretion of $\mathrm{LH}$. Evidence that Sgll is involved in the regulatory processing of $\mathrm{LH}$ strengthens the hypothesis that granins are involved in the regulation of differential secretion of gonadotrophins. This finding paves the way for future investigations in this area, and hypogonadal and transgenic mice will provide ideal physiological model systems to interpret these regulatory mechanisms.

Storage of LH within gonadotrophs is necessary for its rapid and concomitant pulsatile release under the action of 

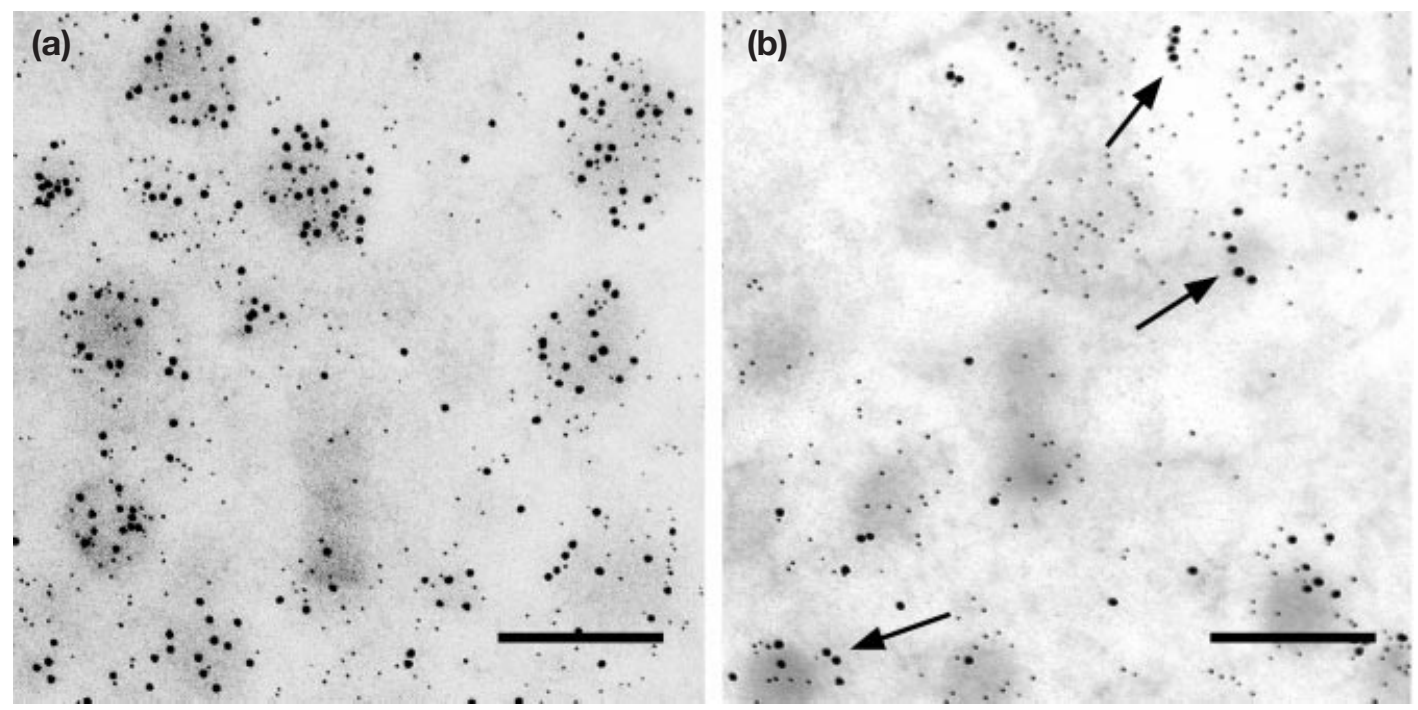

Fig. 4. Transmission electron micrographs of areas of cytoplasm within immunogold-labelled $80 \mathrm{~nm}$ sectioned gonadotrophs that contained granules positive for (a) LH (5 nm) and secretogranin II (Sgll; $15 \mathrm{~nm}$ ), and (b) LH $(5 \mathrm{~nm})$ and FSH $(15 \mathrm{~nm})$ in male mice. Note that gold particles bound to $\mathrm{LH}$ and Sgll were located throughout the matrix of the granules, whereas most of the gold particles bound to FSH are situated near the periphery of the granules (arrows). Scale bars represent $250 \mathrm{~nm}$.
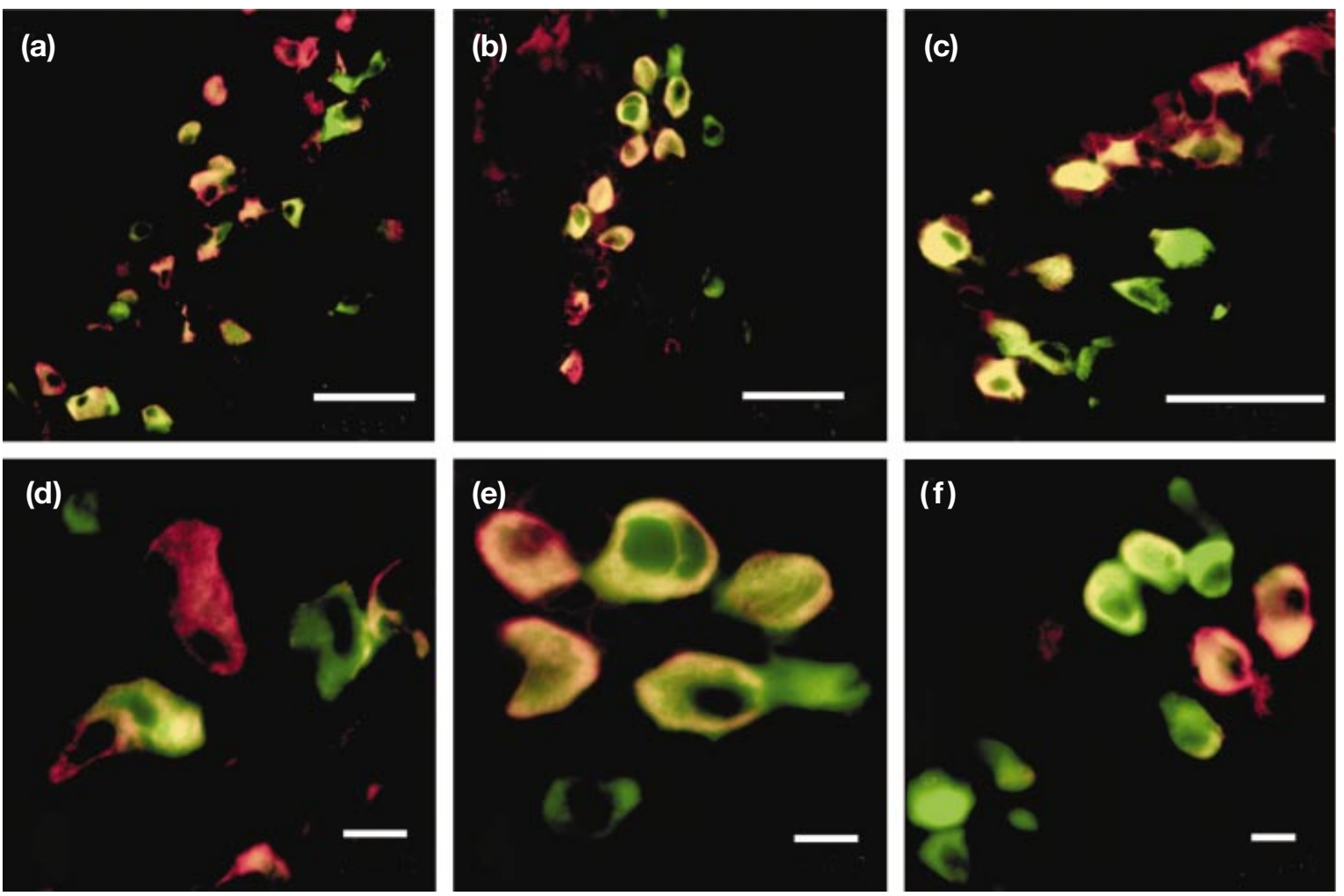

Fig. 5. Localization of $\mathrm{LH}$ (red) and FSH (green) immunofluorescence by confocal microscopy at $(a, b, c)$ low and $(d, e, f)$ high magnification in thick pituitary sections containing gonadotrophs from $(a, d)$ control male mice, or from male mice treated for 2 days with either (b,e) GnRH antiserum $(G / A)$ or $(c, f) G / A$ followed by a bolus of Buserelin $(G / A+B)$. The yellow staining represents areas of dual LH-FSH immunofluorescent labelling within gonadotrophs. Note that LH only, FSH only and co-localized LH-FSH-labelled gonadotrophs were present in animals from all experimental groups. Scale bars represent $(\mathrm{a}, \mathrm{c}, \mathrm{e}) 50 \mu \mathrm{m}$ and $(\mathrm{b}, \mathrm{d}, \mathrm{f}) 10 \mu \mathrm{m}$ 

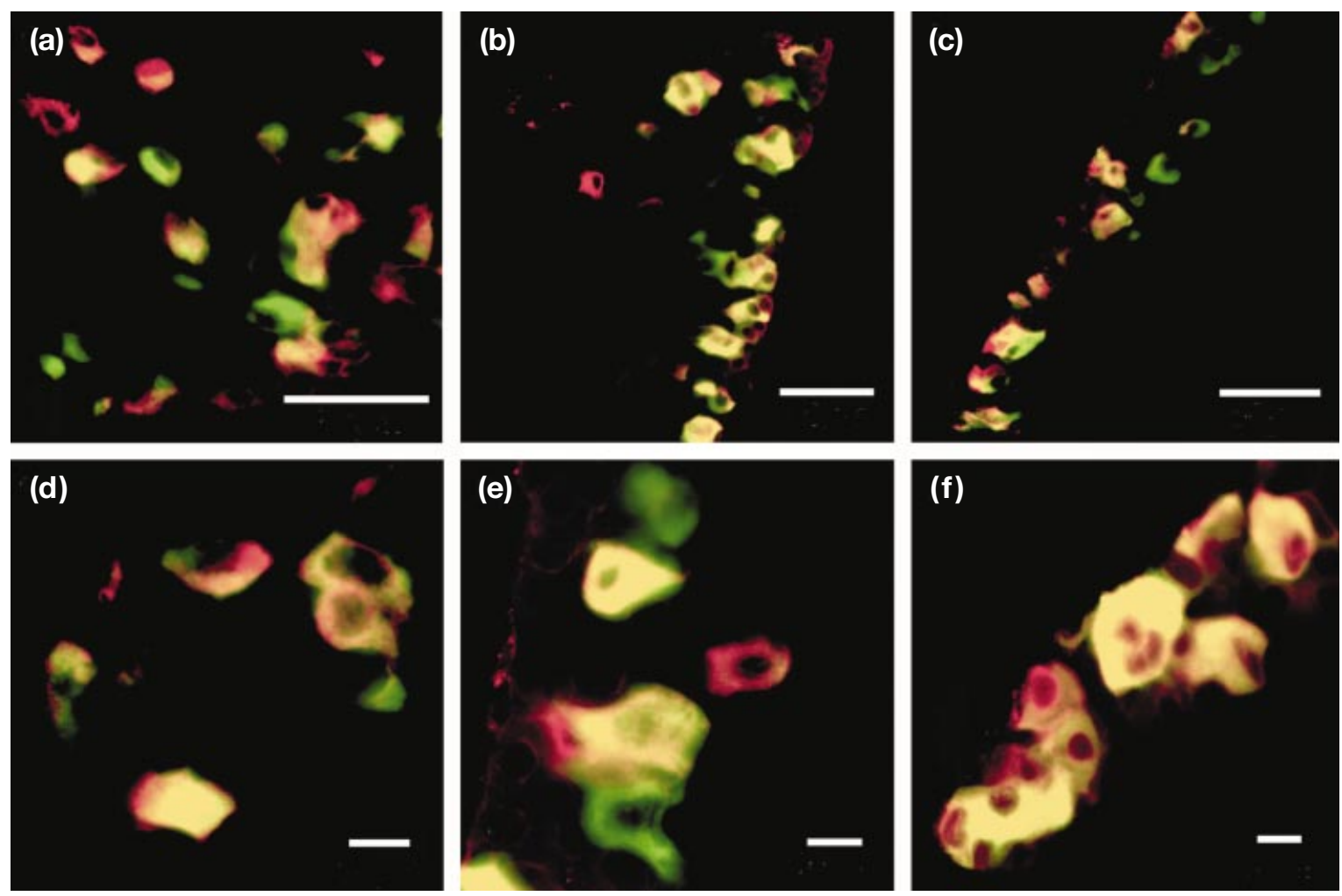

Fig. 6. Localization of LH (red) and secretogranin II (Sgll; green) immunofluorescence by confocal microscopy at (a,b,c) low and $(\mathrm{d}, \mathrm{e}, \mathrm{f})$ high magnification in thick pituitary sections containing gonadotrophs from $(\mathrm{a}, \mathrm{d})$ control male mice, or from male mice treated for 2 days with either $(b, e) \mathrm{GnRH}$ antiserum $(\mathrm{G} / \mathrm{A})$ or $(\mathrm{c}, \mathrm{f}) \mathrm{G} / \mathrm{A}$ followed by a bolus of Buserelin $(G / A+B)$. The yellow staining represents areas of dual LH-Sgll immunofluorescent labelling within gonadotrophs. Note that $\mathrm{LH}$ only, Sgll only and co-localized LH-Sgll-labelled gonadotrophs were present in animals from all experimental groups. Scale bars represent (a,c,e) $50 \mu \mathrm{m}$ and (b,d,f) $10 \mu \mathrm{m}$.

$\mathrm{GnRH}$ and, presumably, is directed at the level of exocytosis. Total intracellular granule storage increased after $\mathrm{GnRH}$ antiserum administration in the present study, which is perhaps not surprising considering that probably negligible amounts of stored $\mathrm{LH}$ were released over the $48 \mathrm{~h}$ treatment period due to the absence of exocytotic-inducing stimulation. The type of granule that appeared to be stored within this $48 \mathrm{~h}$ treatment period was $\mathrm{LH}^{+\mathrm{ve}} / \mathrm{Sgll}+\mathrm{ve}$ granules containing moderately even numbers of both antigens (25-75\% LH-bound and $75-25 \%$ Sgll-bound gold particles). In contrast, there were fewer $\mathrm{LH}^{+\mathrm{ve} / \mathrm{Sgll}}{ }^{\text {-ve }}$ granules in $\mathrm{G} / \mathrm{A}$ mice compared with controls, indicating that this type of granule was continually released during this time.

These changes in granule populations in G/A mice compared with controls were associated with reduced $\mathrm{LH} \beta$ mRNA expression and constant plasma LH concentrations. This latter result may be due to a combination of existing low concentrations of circulating LH in control mice and the possible inability to detect even significant changes in circulating plasma LH concentrations from one sample taken before death due to the pulsatile nature of LH release. However, administration of this $\mathrm{GnRH}$ antiserum in sheep in the follicular stage of the oestrous cycle also did not affect basal concentration of $\mathrm{LH}$, but promptly abolished its pulsatile secretion (McNeilly et al., 1984). Therefore, it is possible that in the present study, GnRH antibody abolished pulsatile LH secretion, while basal concentrations remained unaffected, but the inability to collect blood samples intensively from mice makes it impossible to comment on pulsatile hormone release in this species. Disparity between $\beta$-subunit mRNA expression and plasma concentrations of $\mathrm{LH}$ is well known and is facilitated through the ability of gonadotrophs to store LH (Turgeon et al., 1996). Moreover, changes in stability of $\mathrm{LH} \beta$ mRNA transcript, through alterations in 3'-poly(A) tail length, potentially provide additional means of post-transcriptional regulation of $\mathrm{LH}$ synthesis and are influenced by treatment with GnRH (Weiss et al., 1992), progesterone (Wu and Miller, 1991) and oestradiol (Park et al., 1996), and occur during the follicular phase of the cycle in sheep (Crawford and McNeilly, in press).

Integration of these results not only implies that $\mathrm{LH}^{+\mathrm{ve} / S g l \mid-v e}$ granules were released constitutively to maintain basal $\mathrm{LH}$ concentrations in the present study, but also that Sgll may have been required for increased packaging and storage of $\mathrm{LH}$, as well as perhaps contributing to the exocytotic responsiveness of granules to GnRH stimulation. Alternatively, Sgll secretion may be entirely regulated and, therefore, when exocytosis is blocked, Sgll is also trapped into increased 

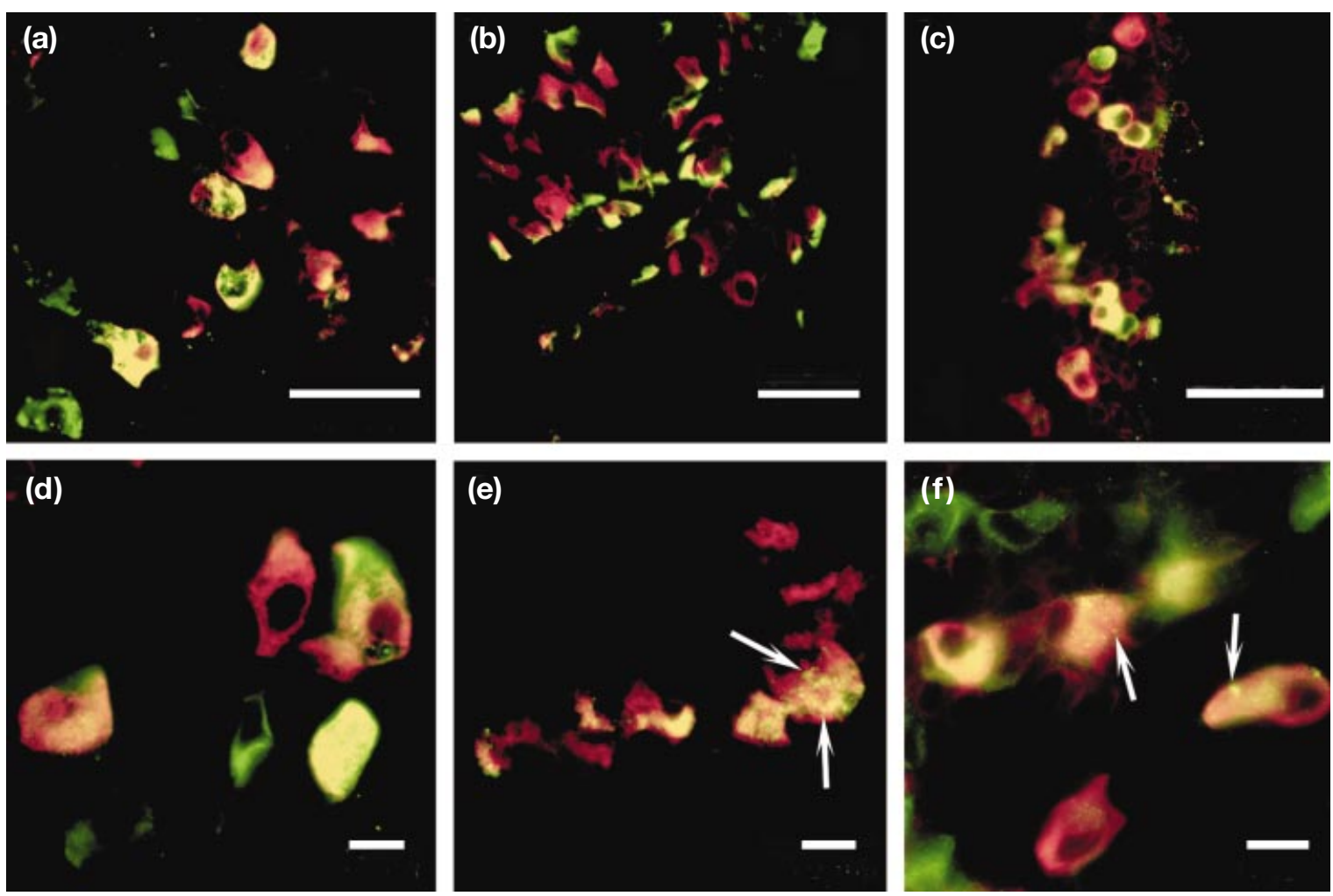

Fig. 7. Localization of LH (red) and CgA (green) immunofluorescence by confocal microscopy at (a,b,c) low and (d,e,f) high magnification in thick pituitary sections containing gonadotrophs from $(a, d)$ control male mice, or from male mice treated for 2 days with either (b,e) $\mathrm{GnRH}$ antiserum $(\mathrm{G} / \mathrm{A})$ or $(\mathrm{C}, \mathrm{f}) \mathrm{G} / \mathrm{A}$ followed by a bolus of Buserelin $(\mathrm{G} / \mathrm{A}+\mathrm{B})$. The yellow staining represents areas of dual $\mathrm{LH}-\mathrm{CgA}$ immunofluorescent labelling within gonadotrophs. Note that LH only, CgA only and co-localized LH-CgA-labelled gonadotrophs were present in animals from all experimental groups. Punctate labelling (arrows) visible at high magnification may be due to compartmentalization of CgA at the periphery of granules. Scale bars represent $(\mathrm{a}, \mathrm{c}, \mathrm{e}) 50 \mu \mathrm{m}$ and $(\mathrm{b}, \mathrm{d}, \mathrm{f}) 10 \mu \mathrm{m}$.

storage. Even though transcription rate for LH $\beta$ had decreased in mice treated with $\mathrm{GnRH}$ antiserum, total granular antigenicity for $\mathrm{LH}$ did not change, indicating that the rate of granule packaging may have slowed to allow intragranular collection of LH equivalent to pretreatment amounts. This was substantiated by increased Sgll content within granules despite constant Sgll mRNA content, and further indicates active aggregation of $\mathrm{LH}$ and Sgll under these conditions.

The significant increase in plasma $\mathrm{LH}$ concentrations in $\mathrm{G} / \mathrm{A}+\mathrm{B}$ mice in the present study verified the ability of Buserelin to bypass the inhibitory actions of $\mathrm{GnRH}$ antibody (Clarke et al., 1978) and indicated that the bulk of LH released in these mice may have been derived from the intracellular stores of gonadotrophs. Indeed, it appeared that the predominant type of granule released after Buserelin treatment was $\mathrm{LH}^{+\mathrm{ve}} / \mathrm{Sgll}{ }^{+v e}$ granules (containing moderately even numbers of both antigen), whereas numbers of $\mathrm{LH}^{+\mathrm{ve}} / \mathrm{Sgll}-\mathrm{ve}$ granules remained unaltered compared with those in $\mathrm{G} / \mathrm{A}$ mice. This finding supports the hypotheses that $\mathrm{LH}^{+\mathrm{ve}} / \mathrm{Sgll}{ }^{+v e}$ granules were released in a regulated fashion in response to $\mathrm{GnRH}$, that $\mathrm{LH}^{+\mathrm{ve}} / \mathrm{SgIl}$-ve granules were released constitutively to maintain basal concentrations of $\mathrm{LH}$ and that Sgll plays an active role in regulated secretion of $\mathrm{LH}$. If this is true, the reduction in numbers of $\mathrm{LH}^{+\mathrm{ve} / \mathrm{SgII}}{ }^{-\mathrm{ve}}$ granules evident after $\mathrm{GnRH}$ antiserum treatment in these mice compared with that in controls indicates that formation of these granules was curbed by a reduced rate of $\mathrm{LH} \beta$ transcription. In other words, these granules may accumulate within the cytoplasm as a net result of varying LH $\beta$ mRNA content and steady exocytotic rates, which may be under autocrine control and not due to regulated storage.

The marked attenuation in plasma FSH concentrations after administration of $\mathrm{GnRH}$ antiserum, in conjunction with unaltered FSH $\beta$ mRNA content, indicates that a proportion of FSH is released via the regulated secretory pathway. This contention was confirmed by the action of Buserelin, which resulted in increased plasma FSH concentrations, presumably from release of intracellular FSH stores. Unfortunately, as a result of the sensitivity of FSH and CgA antigenicity to TEM processing methods, very little of either of these antigens was detected within granules in the present study. Therefore, due to the limited information obtained on $\mathrm{FSH}$ and $\mathrm{CgA}$, no conclusions can be drawn with respect to the relationship between granin and FSH storage and synthesis.

In the few granules in which specific FSH label was observed, FSH appeared to be situated preferentially near the periphery of the granule, although the granular 
membrane was not easily definable. In contrast, strong and sensitive labelling of $\mathrm{LH}$ and Sgll revealed their location throughout the matrix of the granule. This partitioning has also been reported in rat gonadotrophs (Watanabe et al., 1993, 1998b). Indeed, compartmentalization of stored CgA was thought to be responsible for the punctate labelling of CgA observed by confocal microscopy in the present study. Recent studies have identified $\mathrm{IP}_{3}$ receptors on membranes of secretory granules, as well as $\mathrm{IP}_{3}$ receptor-binding sites on CgA (for a review, see Yoo, 2000), and, therefore, CgA may serve as a gate-keeper in the sorting of gonadotrophins (Arvan and Castle, 1998) and facilitate granule membraneplasma membrane interactions at the event of exocytosis. The increase in CgA-only cells observed by confocal microscopy in $\mathrm{G} / \mathrm{A}+\mathrm{B}$ mice in the present study indicates that CgA may not be released after Buserelin administration, but may be recycled together with the granule membrane. Although early immunocytochemical studies showed localization of the three major granins to within gonadotrophs and a few corticotrophs, whereas most thyrotrophs contained CgA and a few contained SgIl (O'Connor et al., 1983; Cohn et al., 1984; Rosa et al., 1985; Rundle et al., 1986; Hearn; 1987), GnRH receptors are only present on gonadotrophs in the anterior pituitary gland.

The characteristic morphology of regulated secretory cells is the accumulation of secretory granules (Burgess and Kelly, 1987). The pathway of formation of nascent storage granule begins with a protrusion of the trans-Golgi network to create a condensing vacuole (Palade, 1975; Novikoff et al., 1977) that transforms into an immature granule capable of stimulus-dependent secretion (Arvan et al., 1991; Tooze et al., 1991) only on detachment from the trans-Golgi network (Tooze and Tooze, 1986). Maturation of an immature granule to a mature secretory granule involves an apparent reduction in volume and surface area (Sesso et al., 1980), as well as an increase in dry-mass concentration (Wong et al., 1991) that results in an extremely stable electron-dense core (Tooze and Tooze, 1986), which may be separated from the membrane by a 'halo of space' (Burgess and Kelly, 1987). It was interesting to note the dichotomy of granule morphology observed in the present study. Equal proportions of entirely electron-lucent granules (presumably immature granules) and granules that contained an electron-dense core surrounded by an electrondense outer region (presumably mature granules) were observed in control mice. However, these 'presumptive mature' granules were the prevalent type of granule in G/A mice, probably due to increased storage time caused by the block on stimulated exocytosis. Conversely, presumptive immature granules were the predominant type of granule in $\mathrm{G} / \mathrm{A}+\mathrm{B}$ mice, indicating that it was presumptive 'mature' granules that were preferentially released after exocytotic stimulation. Despite immature granules being capable of stimulus-dependent secretion (Arvan et al., 1991; Tooze et al., 1991), it is possible that mature granules have a higher affinity for granule membrane-plasma membrane fusion that is required for exocytosis.
In conclusion, removal of $\mathrm{GnRH}$ input reduced $\mathrm{LH} \beta$ mRNA content but did not affect basal plasma LH concentrations. In combination with increased storage of $\mathrm{LH}^{+\mathrm{ve}} / \mathrm{SgII}+\mathrm{ve}$ granules, decreased storage of $\mathrm{LH}^{+\mathrm{ve}} / \mathrm{SgII}$-ve granules and overall augmentation of intragranular antigenicity of Sgll indicate that SgII and LH actively co-aggregate to promote intracellular granule storage in the absence of $\mathrm{GnRH}$ input. In addition, $\mathrm{LH}^{+\mathrm{ve}} / \mathrm{Sg} \mathrm{Il}^{-\mathrm{ve}}$ granules appeared to have been destined for constitutive release and may have functioned to maintain basal LH concentrations, whereas $\mathrm{LH}^{+\mathrm{ve}} / \mathrm{SgII}+\mathrm{ve}$ granules appeared to have been sorted into the regulated pathway and were under the direct influence of $\mathrm{GnRH}$. The absence of GnRH action on the pituitary did not alter FSH $\beta$ mRNA content but resulted in attenuated plasma $\mathrm{FSH}$ concentrations, indicating that a proportion of FSH had been sorted into storage at this time. Subsequent stimulation by Buserelin caused a marked release of intracellular $\mathrm{LH}^{+\mathrm{ve}} / \mathrm{SgII}+\mathrm{ve}$ granule stores, reflected as a detectable increase in both plasma $\mathrm{LH}$ and $\mathrm{FSH}$ concentrations, whereas $\mathrm{LH}^{+\mathrm{ve}} / \mathrm{Sg} \mathrm{Il}^{-\mathrm{ve}}$ granules were not released.

J. L. Crawford was supported by a Post-doctorate fellowship from the Journal of Reproduction and Fertility Ltd.

\section{References}

Arvan P and Castle D (1998) Review article: sorting and storage during secretory granule biogenesis: looking backward and looking forward Biochemistry Journal 332 593-610

Arvan P, Kuliawat R, Prabakaran D, Zavacki AM, Elahi D, Wang S and Pilkey D (1991) Protein discharge from immature secretory granules displays both regulated and constitutive characteristics Journal of Biological Chemistry 26614 171-14 174

Berryman MA and Rodewald RD (1990) An enhanced method for postembedding immunocytochemical staining which preserves cell membranes Journal of Histochemistry and Cytochemistry 38 159-170

Burgess TL and Kelly RB (1987) Constitutive and regulated secretion of proteins Annual Review of Cell Biology 3 243-293

Chanat E, Weiss U, Huttner WB and Tooze SZ (1993) Reduction of the disulfide bond of chromogranin B (secretogranin I) in the trans-Golgi network causes its missorting to the constitutive secretory pathway EMBO Journal 12 2159-2168

Chanat E, Weiß U and Huttner WB (1994) The disulfide bond in chromogranin $B$, which is essential for its sorting to secretory granules, is not required for its aggregation in the trans-Golgi network FEBS Letters $351225-230$

Clarke IJ and Cummins JT (1982) The temporal relationship between gonadotropin releasing hormone $(\mathrm{GnRH})$ and luteinizing hormone $(\mathrm{LH})$ secretion in ovariectomized ewes Endocrinology 111 1737-1739

Clarke IJ, Fraser HM and McNeilly AS (1978) Active immunization of ewes against luteinizing hormone releasing hormone, and its effects on ovulation and gonadotrophin, prolactin and ovarian steroid secretion Journal of Endocrinology 78 39-47

Cohn DV, Elting JJ, Frick M and Elde R (1984) Selective localization of the parathyroid secretory protein-l/adrenal medulla chromogranin A protein family in a wide variety of endocrine cells of the rat Endocrinology 114 1963-1974

Cool DR, Normant E, Shen F-S, Chen H-C, Pannell L, Zhang Y and Loh YP (1997) Carboxypeptidase $\mathrm{E}$ is a regulated secretory pathway sorting receptor: genetic obliteration leads to endocrine disorders in $C p e^{f a t}$ mice Cell 88 73-83

Cozzi MG and Zanini A (1986) Sulfated LH subunits and tyrosine-sulfated secretory protein (secretogranin II) in female rat adenohypophyses: changes with age and stimulation of release by LHRH Molecular and Cellular Endocrinology 44 47-54

Crawford JL and McNeilly AS (2002) Co-localisation of gonadotrophins and 
granins in gonadotrophs at different stages of the oestrous cycle in sheep Journal of Endocrinology (in press)

Crawford JL, Currie RJW and McNeilly AS (2000) Replenishment of LH stores of gonadotrophs in relation to expression, synthesis and secretion of $\mathrm{LH}$ after the preovulatory phase of the sheep oestrous cycle Journal of Endocrinology 167 453-463

Farnworth PG (1995) Gonadotrophin secretion revisited. How many ways can FSH leave a gonadotroph? Journal of Endocrinology 145 387-395

Farnworth PG, Robertson DM, de Kretser DM and Burger HG (1988) Effects of 31 kilodalton bovine inhibin on follicle-stimulating hormone and luteinizing hormone in rat pituitary cells in vitro: actions under basal conditions Endocrinology 122 207-213

Fraser HM, Clarke IJ and McNeilly AS (1981) Effect of oestrogen and an LH$\mathrm{RH}$ agonist on the release of gonadotrophins in ovariectomized ewes deprived of LH-RH Journal of Reproduction and Fertility 62 131-140

Gerdes HH, Rosa P, Phillips E, Baeuerle PA, Frank R, Argos P and Huttner WB (1989) The primary structure of human secretogranin II, a widespread tyrosine-sulfated secretory granule protein that exhibits low $\mathrm{pH}$ - and calcium-induced aggregation Journal of Biological Chemistry 26412 009-12 015

Glombik MM, Krömer A, Salm T, Huttner WB and Gerdes H-H (1999) The disulfide-bonded loop of chromogranin B mediates membrane binding and directs sorting from the trans-golgi network to secretory granules EMBO Journal 18 1059-1070

Gorr S-U, Shioi J and Cohn DV (1989) Interaction of calcium with porcine adrenal chromogranin A (secretory protein-I) and chromogranin B (secretogranin I) American Journal of Physiology 257 E247-E254

Hearn SA (1987) Electron microscopic localisation of chromogranin A in osmium-fixed neuroendocrine cells with a protein A-gold technique Journal of Histochemistry and Cytochemistry 35 795-801

Jeziorowski T, Watanabe T, Bargsten G and Grube D (1997) Heterogeneity of pituitary gonadotrope cells in male rats Archives of Histology and Cytology $60355-370$

Krömer A, Glombik MM, Huttner WB and Gerdes H-H (1998) Essential role of the disulphide-bonded loop of chromogranin B for sorting to secretory granules is revealed by expression of a deletion mutant in the absence of endogenous granin synthesis Journal of Cell Biology 140 1331-1346

Levine JE, Norman RL, Gliessman PM, Oyama TT, Bangsberg DR and Spies HG (1985) In vivo gonadotropin-releasing hormone release and serum luteinizing hormone measurements in ovariectomized, estrogen-treated rhesus macaques Endocrinology 117 711-721

McNeilly AS, Fraser HM and Baird DT (1984) Effect of immunoneutralization of $\mathrm{LH}$ releasing hormone on $\mathrm{LH}, \mathrm{FSH}$ and ovarian steroid secretion in the preovulatory phase of the oestrous cycle in the ewe Journal of Endocrinology 101 213-219

McNeilly JR, Brown P, Clark AJ and McNeilly AS (1991) Gonadotrophinreleasing hormone modulation of gonadotrophins in the ewe: evidence for differential effects on gene expression and hormone secretion Journal of Molecular Endocrinology 7 35-43

McNeilly JR, Brown P, Mullins J, Clark AJ and McNeilly AS (1996) Characterization of the ovine LH $\beta$-subunit gene: the promoter is regulated by $\mathrm{GnRH}$ and gonadal steroids in transgenic mice Journal of Endocrinology 151 481-489

McNeilly JR, Saunders PTK, Taggart M, Cranfield M, Cooke HJ and McNeilly AS (2000) Loss of oocytes in Dazl knockout mice results in maintained ovarian steroidogenic function but altered gonadotropin secretion in adult animals Endocrinology 141 4284-4294

Matteri RL, Roser JF, Baldwin DM, Lipovetsky V and Papkoff H (1987) Characterization of a monoclonal antibody which detects luteinizing hormone from diverse mammalian species Domestic Animal Endocrinology 4 157-165

Novikoff AB, Mori M, Quintana N and Yam A (1977) Studies of the secretory process in the mammalian exocrine pancreas. I. The condensing vacuoles Journal of Cell Biology 75 148-165

O'Connor DT, Burton D and Deftos LJ (1983) Chromogranin A: immunohistology reveals its universal occurrence in normal poly-peptide hormone producing endocrine glands Life Sciences 33 1657-1663

Palade GE (1975) Intracellular aspects of the process of protein synthesis Science $23025-32$
Park D, Cheon M, Kim C and Ryu K (1996) Progesterone together with estradiol promotes luteinising hormone $\beta$-subunit mRNA stability in rat pituitary cells cultured in vitro. European Journal of Endocrinology 134 236-242

Reiffen FU and Gratzl M (1986) $\mathrm{Ca}^{2+}$ binding to chromaffin vesicle matrix proteins: effect of $\mathrm{pH}, \mathrm{Mg}^{2+}$, and ionic strength Biochemistry 25 4402-4406

Rosa P, Hille A, Lee RWH, Zanini A, de Camilli P and Huttner WB (1985) Secretogranins I and II: two tyrosine-sulfated secretory proteins common to a variety of cells secreting peptides by the regulated pathway Journal of Cell Biology 101 1999-2011

Rundle S, Somogyi P, Fischer-Colbrie R, Hagn C, Winkler H and Chubb IW (1986) Chromogranin A, B and C: immunohistochemical localization in ovine pituitary and the relationship with hormone-containing cells Regulatory Peptides 16 217-233

Sesso A, Assis JE, Kuwajima VY and Kachar B (1980) Freeze-fracture and thin-section study of condensing vacuoles in rat pancreatic acinar cells Acta Anatomica $108521-539$

Thiele C and Huttner WB (1998) The disulfide-bonded loop of chromogranins, which is essential for sorting to secretory granules, mediates homodimerization Journal of Biological Chemistry 273 1223-1231

Tooze J and Tooze SA (1986) Clathrin-coated vesicular transport of secretory proteins during the formation of ACTH-containing secretory granules in AtT20 cells Journal of Cell Biology 103 839-850

Tooze SA, Flatmark T, Tooze J and Huttner WB (1991) Characterization of the immature secretory granule, an intermediate in granule biogenesis Journal of Cell Biology 115 1491-1503

Turgeon JL, Kimura Y, Waring DW and Mellon PL (1996) Steroid and pulsatile gonadotropin-releasing hormone $(\mathrm{GnRH})$ regulation of luteinizing hormone and $\mathrm{GnRH}$ receptor in a novel gonadotrope cell line Molecular Endocrinology 10 439-450

Watanabe T, Uchiyama Y and Grube D (1991) Topology of chromogranin A and secretogranin II in the rat anterior pituitary: potential marker proteins for distinct secretory pathways in gonadotrophs Histochemistry 96 285-293

Watanabe T, Jeziorowski T, Wuttke W and Grube D (1993) Secretory granules and granins in hyperstimulated male rat gonadotropes Journal of Histochemistry and Cytochemistry 41 1801-1812

Watanabe T, Banno T, Jeziorowski T, Ohsawa Y, Waguri S, Grube D and Uchiyama Y (1998a) Effects of sex steroids on secretory granule formation in gonadotropes of castrated male rats with respect to granin expression Endocrinology 139 2765-2773

Watanabe Y, Azuma T, Banno T, Jeziorowski T, Ohsawa Y, Waguri S, Grube D and Uchiyama $\mathbf{Y}$ (1998b) Immunocytochemical localization of chromogranin A and secretogranin II in female rat gonadotropes Archives of Histology and Cytology 61 99-113

Weiss J, Crowley WF, Jr and Jameson JL (1992) Pulsatile gonadotropinreleasing hormone modifies polyadenylation of gonadotropin subunit messenger ribonucleic acids Endocrinology 130 415-420

Wong JG, Izutsu KT, Robinovitch MR, Iversen JM, Cantino ME and Johnson DE (1991) Microprobe analysis of maturation-related elemental changes in rat parotid secretory granules American Journal of Physiology $\mathbf{2 6 1}$ C1033-1041

Wu JC and Miller WL (1991) Progesterone shortens poly(A) tails of the mRNAs of alpha and beta subunits of ovine luteinizing hormone Biology of Reproduction 45 215-220

Yoo SH (1994) pH-dependent interaction of chromogranin A with integral membrane proteins of secretory vesicle including 260-kDa protein reactive to inositol 1,4,5-triphosphate receptor antibody Journal of Biological Chemistry 26912 001-12 006

Yoo SH (2000) Coupling of the $\mathrm{IP}_{3}$ receptor/Ca ${ }^{2+}$ channel with $\mathrm{Ca}^{2+}$ storage proteins chromogranins A and B in secretory granules TINS 23 424-428

Yoo SH and Kang YK (1997) Identification of the secretory vesicle membrane binding region of chromogranin B FEBS Letters 406 259-262

Yoo SH, So SH, Kweon HS, Lee JS, Kang MK and Jeon CJ (2000) Coupling of the inositol 1,4,5-triphosphate receptor and chromogranins $A$ and $B$ in secretory granules Journal of Biological Chemistry 27512 553-12 559

Received 4 February 2002.

First decision 4 March 2002.

Accepted 15 April 2002. 